\title{
Dietary nano-dicalcium phosphate improves immune response and intestinal morphology of broiler chickens
}

\author{
M.D. Makola ${ }^{1}$, L.E. Motsei ${ }^{1,2}$, T.O. Ajayi ${ }^{3}$ \& A.O. Yusuf ${ }^{\# 1,2,3}$ \\ ${ }^{1}$ Department of Animal Science, Faculty of Agriculture, Science and Technology, North-West University, South Africa \\ ${ }^{2}$ Food Security and Safety Niche Area, Faculty of Natural and Agricultural Sciences, North-West University, South Africa \\ ${ }^{3}$ Department of Animal Production and Health, Federal University of Agriculture, PMB, 2240, Abeokuta, Nigeria
}

(Received 14 January 2021; Accepted 9 March 2021; Published 21 May 2021)
Copyright resides with the authors in terms of the Creative Commons Attribution 4.0 South African Licence.
See: http://creativecommons.org/licenses/by/4.0/za
Condition of use: The user may copy, distribute, transmit and adapt the work, but must recognise the authors and the South African Journal of Animal Science.

\begin{abstract}
Various levels of substitution of nano-dicalcium phosphate $\left(\mathrm{nCaHPO}_{4}\right)$ for the calcium and phosphorus supplied by limestone and monocalcium phosphate were evaluated, based on weight change, serum constituents, immune response and intestinal morphology of broiler chickens. The birds were assigned to five dietary treatments containing $0 \%$ (control), $40 \%, 60 \%, 80 \%$, and $100 \%$ substitution levels of $\mathrm{nCaHPO}_{4}$ from days 0 to 42 . Data were collected for blood measurement and intestinal morphology and analysed with one-way analysis of variance. Feeds substituted with $40 \% \mathrm{nCaHPO}_{4}$ showed a higher mean value of final weight and better feed conversion. The results revealed similar haematological parameters across the treatment groups. At the same time, $\mathrm{nCaHPO}_{4}$ influenced most of the serum biochemical constituents, such as calcium, phosphorus, glucose, albumin, and total protein. High concentrations of total protein were observed for birds fed $60 \% \mathrm{nCaHPO}_{4}$ compared with other treatments. The highest comparable means for albumin were observed in birds fed $40 \%$ and $60 \%$ nCaHPO4. Cholesterol levels were increased when birds were fed $0 \%$ and $40 \%$ of diets. Elevated serum phosphorus concentration was observed when $0 \%, 40 \%$, $60 \%$ and $100 \%$ substitution levels were fed, whereas $80 \%$ presented the least mean value. The results also showed that birds fed $40 \%$ nano-dicalcium phosphate had the highest villi length, which signified improved absorption of minerals. In conclusion, $40 \%$ and $60 \%$ levels of $\mathrm{nCaHPO}_{4}$ could be used to boost immune response and functional intestinal morphology of broiler chicken with no negative effect on haematological parameters.
\end{abstract}

Keywords: blood profile, intestinal morphology, nanoparticles, poultry

"Corresponding author: yusufao@funaab.edu.ng

\section{Introduction}

Nanotechnology is gaining ground in veterinary and animal sciences by supplying minute scales that are vital for living organisms. The application of minerals in nano form showed improvement in feeding efficiency, minimizing losses from animal diseases, and converting animal by-products into value-added products (Chen \& Yada, 2011). Nanomaterials have potential in a range of environmental applications owing to their extremely small particle size, large surface area, and high reactivity (Huang et al., 2015). Research into the adoption of nanominerals in poultry production is necessary to grasp the advantages of nanomaterials and to curb food insecurity. McDonald et al. (2010) documented that various body processes require adequate amounts of minerals for proper growth and development. Minerals occur in body fluids and tissues as electrolytes concerned with the maintenance of osmotic pressure, acid-base balance, membrane permeability and transmission of nerve impulses.

The utilization rate of nanominerals is much higher than that of conventional inorganic and organic minerals because nanoparticles may enter the animal body through direct penetration (Talaat, 2017). Nanominerals can penetrate the small intestines and distribute into the blood, brain, lung, heart, kidney, spleen, liver, and intestine by absorption in the stomach (Hillyer \& Albrecht, 2001) for immediate use and to rectify anomalies. 
Modern commercial broilers are always faced with challenges, which include immunological stress, pathogen infection and environmental stress. These challenges instigate non-essential immune responses, resulting in inadequate production, host tissue damage and clinical diseases (Nie_et al., 2018). Immunological and oxidative stress can be caused by lipopolysaccharide intolerance and other factors. These might affect the physiological and biochemical processes of animals and interfere with their normal metabolism and functions, resulting in production losses (Nie et al., 2018). To achieve optimum growth and production potential in modern broilers, poultry diets must be formulated to provide birds with all required nutrients in adequate amounts (Daghir, 2009). This study therefore set out to evaluate the influence in broiler diets of various levels of nano-dicalcium phosphate on blood parameters, immune response and intestinal morphology. Its results would assist farmers and animal nutritionists to establish the most efficient levels of $\mathrm{nCaHPO}$ during the production period.

\section{Materials and Methods}

The experiment commenced after ethical approval by North-West University Animal Production Sciences Research Ethics Committee (NWU-AnimalProdREC) with approval number NWU0070118A5. The study was carried out on Rooigront Farm in North West, which is located $16 \mathrm{~km}$ south-east of the capital city, Mafikeng. The annual rainfall of this area is between 300 and $700 \mathrm{~mm}$. Summer rainfall occurs between October and March, and winter brings dry sunny days and chilly nights. The geographical coordinates are $25^{\circ} 55^{\prime} 0$ " S, $25^{\circ} 48^{\prime} 0$ " E.

A total of 240 day-old broiler chicks were used. Nano-dicalcium phosphate $\left(\mathrm{nCaHPO}_{4}\right)$ with a particle size of $40 \mathrm{~nm}$ was purchased from Mknano, Ontario, Canada. All diets were formulated in accordance with the requirements for broiler chickens (Applegate \& Angel, 2014). Dietary treatments were created by replacing conventional monocalcium phosphate and limestone with $\mathrm{nCaHPO}_{4}$. The starter, grower and finisher diets were formulated by a commercial feed manufacturer in Centurion, Gauteng, South Africa with replacement levels of $0 \%, 40 \%, 60 \%, 80 \%$, and $100 \% \mathrm{nCaHPO}_{4}$ (Table 1). The diets were isocaloric within a growth phase, but increased progressively in energy density from the starter phase to the finishing phase. The nutritional values of the diets are shown in Table 2. The five treatments were each replicated four times. Day-old chicks were weighed individually and distributed randomly in groups of twelve birds per replicate. in preparation for the arrival of the birds the house was cleaned thoroughly and disinfected and the drinkers and feeding troughs were ashed, clean and dried. Fresh water and feeds were given to the chickens daily ad libitum. Lights were switched on continuously for the first two weeks of the experiment. Fresh wood shavings were used for bedding and were spread to a depth of seven centimetres. The birds were housed in floor pens and the dietary treatments were randomly allocated to the pens.

Blood samples were collected at the end of the feeding trial (six weeks) from four randomly selected birds from each replicate. The wing vein of birds was punctured using the needle set and syringes of about 5 $\mathrm{ml}$. EDTA vacutainer tubes were used to collect about $2 \mathrm{ml}$ of plasma, and another $2 \mathrm{ml}$ was collected in the red stoppered tubes for serum. The blood samples for haematology were placed in a cooler box with ice and transported to the laboratory for analysis. Red blood cells, haemoglobin, monocytes, eosinophil, and lymphocytes were determined with IDEXX LaserCyte. The blood chemistry analysis was carried out with IDEXX VetTest Chemistry Analyser and total protein, albumin, total cholesterol, calcium, inorganic phosphorus, globulin, alanine transaminase, and alkaline phosphatase were analysed.

To establish intestinal morphology, twelve birds per treatment were randomly selected and slaughtered. The small intestine tissue sample (duodenum, jejunum and ileum) fragments were obtained later and fixed in a mixture of $10 \%$ buffered formalin solution, processed with paraffin embedding, and stained with haematoxylin and eosin (H\&E) (Anwar, 2013). Measurements of the cross-sections of the slides were then evaluated under a microscope to obtain the length of villi and width for the duodenum, jejunum and ileum using Zen software.

The GLM procedure of SAS (SAS Institute, Inc., Cary, North Carolina, USA) was used to analyse data for serum constituents and intestinal morphology using this linear model:

$$
Y_{i j}=\mu+D_{i}+e_{i j}
$$

where: $Y_{i j}=$ a dependent variable recorded for the jth bird that was fed the ith diet $\left(D_{i}\right)$,

$\mu=$ the overall mean, and

$e_{i j}=$ the random error associated with an observation.

Collectively the errors were assumed to be normally and independently distributed. For all statistical tests, significance was declared at $P<0.05$. Least square means were compared using the PDIFF option of the LSMEANS statement. 
Table 1 Ingredients in starter, grower and finishing diets for broilers formulated with various levels of nano-dicalcium phosphate to replace limestone and monocalcium phosphate

\begin{tabular}{|c|c|c|c|c|c|c|c|c|c|c|c|c|c|c|c|}
\hline \multirow{3}{*}{ Ingredients, g/kg } & \multicolumn{15}{|c|}{ Nano-dicalcium phosphate level } \\
\hline & \multicolumn{3}{|c|}{$0 \%$} & \multicolumn{3}{|c|}{$40 \%$} & \multicolumn{3}{|c|}{$60 \%$} & \multicolumn{3}{|c|}{$80 \%$} & \multicolumn{3}{|c|}{$100 \%$} \\
\hline & $S$ & $\mathrm{G}$ & $\mathrm{F}$ & $S$ & G & $\mathrm{F}$ & $S$ & G & $\mathrm{F}$ & $S$ & $\mathrm{G}$ & $\mathrm{F}$ & S & G & $\mathrm{F}$ \\
\hline Yellow maize & 595.3 & 634.2 & 651.6 & 598.9 & 636.8 & 653.9 & 600.7 & 638.1 & 654.8 & 602.4 & 639.3 & 655.8 & 604.7 & 640.9 & 657.0 \\
\hline Prime gluten & & & 10.0 & & & 10.0 & & & 10.0 & & & 10.0 & & & 10.0 \\
\hline Extruded full fat soybean & 120.5 & 120.0 & 120.0 & 113.9 & 120.0 & 120.0 & 110.7 & 120.0 & 120.0 & 107.4 & 120.0 & 120.0 & 103.2 & 120.0 & 120.0 \\
\hline Soybean & 210.5 & 168.4 & 138.7 & 215.0 & 168.1 & 138.5 & 217.2 & 167.9 & 138.4 & 219.5 & 167.8 & 138.2 & 222.5 & 167.6 & 138.1 \\
\hline Sunflower & 35.0 & 35.0 & 35.0 & 35.0 & 35.0 & 35.0 & 35.0 & 35.0 & 35.0 & 35.0 & 35.0 & 35.0 & 35.0 & 35.0 & 35.0 \\
\hline Hydroxyapatite & & & & 3.64 & 3.14 & 2.31 & 5.46 & 4.71 & 3.47 & 7.29 & 6.27 & 4.63 & 9.67 & 8.29 & 6.12 \\
\hline Limestone & 12.52 & 11.93 & 11.14 & 10.76 & 10.42 & 10.03 & 9.88 & 9.67 & 9.47 & 9.00 & 8.91 & 8.91 & 7.85 & 7.94 & 8.20 \\
\hline Monocalcium phosphate & 9.11 & 7.84 & 5.78 & 5.68 & 4.88 & 3.60 & 3.96 & 3.39 & 2.50 & 2.25 & 1.91 & 1.41 & & & \\
\hline Salt & 1.79 & 1.83 & 2.01 & 1.79 & 1.83 & 2.01 & 1.78 & 1.83 & 2.01 & 1.78 & 1.83 & 2.01 & 1.78 & 1.83 & 2.01 \\
\hline Sodium bicarbonate & 2.19 & 2.15 & 1.52 & 2.19 & 2.15 & 1.53 & 2.20 & 2.15 & 1.53 & 2.20 & 2.15 & 1.53 & 2.20 & 2.15 & 1.53 \\
\hline DL-Methionine & 3.19 & 2.74 & 2.17 & 3.19 & 2.73 & 2.16 & 3.19 & 2.73 & 2.16 & 3.18 & 2.73 & 2.16 & 3.18 & 2.73 & 2.16 \\
\hline L-Threonine & 4.06 & 3.66 & 2.74 & 4.07 & 3.66 & 2.75 & 4.07 & 3.66 & 2.75 & 4.06 & 3.66 & 2.75 & 4.07 & 3.66 & 2.75 \\
\hline Soybean oil mixer & & 6.76 & 14.34 & & 5.88 & 13.68 & & 5.44 & 13.35 & & 5.00 & 13.02 & & 4.43 & 12.60 \\
\hline Lignobond & 2.00 & 2.00 & 2.00 & 2.00 & 2.00 & 2.00 & 2.00 & 2.00 & 2.00 & 2.00 & 2.00 & 2.00 & 2.00 & 2.00 & 2.00 \\
\hline Broiler premix & 3.00 & 2.50 & 2.00 & 3.00 & 2.50 & 2.00 & 3.00 & 2.50 & 2.00 & 3.00 & 2.50 & 2.00 & 3.00 & 2.50 & 2.00 \\
\hline AxtraPhy phytase enzyme & 0.10 & 0.10 & 0.10 & 0.10 & 0.10 & 0.10 & 0.10 & 0.10 & 0.10 & 0.10 & 0.10 & 0.10 & 0.10 & 0.10 & 0.10 \\
\hline Salinomycin 12\% & 0.50 & 0.50 & 0.50 & 0.50 & 0.50 & 0.50 & 0.50 & 0.50 & 0.50 & 0.50 & 0.50 & 0.50 & 0.50 & 0.50 & 0.50 \\
\hline
\end{tabular}

S: starter diet, G: grower diet, F: finishing diet 
Table 2 Nutritional contents of starter, grower and finishing diets for broilers formulated with various levels of nano-dicalcium phosphate to replace limestone and monocalcium phosphate

\begin{tabular}{|c|c|c|c|c|c|c|c|c|c|c|c|c|c|c|c|}
\hline \multirow{3}{*}{ Nutrients } & \multicolumn{15}{|c|}{ Nano-dicalcium phosphate level } \\
\hline & \multicolumn{3}{|c|}{$0 \%$} & \multicolumn{3}{|c|}{$40 \%$} & \multicolumn{3}{|c|}{$60 \%$} & \multicolumn{3}{|c|}{$80 \%$} & \multicolumn{3}{|c|}{$100 \%$} \\
\hline & $S$ & $\mathrm{G}$ & $\mathrm{F}$ & $S$ & $\mathrm{G}$ & $\mathrm{F}$ & $S$ & G & $\mathrm{F}$ & $S$ & $\mathrm{G}$ & $\mathrm{F}$ & $S$ & $\mathrm{G}$ & $\mathrm{F}$ \\
\hline Dry matter, $\mathrm{g} / \mathrm{kg}$ & 885.4 & 884.6 & 884.4 & 885.1 & 884.3 & 884.2 & 885.0 & 884.2 & 884.1 & 884.9 & 884.1 & 884.0 & 884.8 & 883.9 & 883.9 \\
\hline ME poultry, MJ/kg & 12.6 & 12.9 & 13.3 & 12.6 & 12.9 & 13.3 & 12.6 & 12.9 & 13.3 & 12.6 & 12.9 & 13.3 & 12.6 & 12.9 & 13.3 \\
\hline Crude protein, $\mathrm{g} / \mathrm{kg}$ & 208.1 & 190.6 & 182.9 & 208.1 & 190.7 & 183.0 & 208.1 & 190.7 & 183.0 & 208.2 & 190.7 & 183.0 & 208.2 & 190.8 & 183.0 \\
\hline Lysine, g/kg & 13.20 & 11.90 & 10.59 & 13.20 & 11.90 & 10.59 & 13.20 & 11.90 & 10.59 & 13.20 & 11.90 & 10.59 & 13.20 & 11.90 & 10.59 \\
\hline Methionine, $\mathrm{g} / \mathrm{kg}$ & 6.47 & 5.80 & 5.22 & 6.46 & 5.80 & 5.22 & 6.46 & 5.80 & 5.22 & 6.46 & 5.79 & 5.22 & 6.46 & 5.79 & 5.21 \\
\hline Sulfur amino acids, $\mathrm{g} / \mathrm{kg}$ & 9.80 & 8.91 & 8.28 & 9.80 & 8.91 & 8.28 & 9.80 & 8.91 & 8.28 & 9.80 & 8.91 & 8.28 & 9.80 & 8.91 & 8.28 \\
\hline Threonine, g/kg & 8.83 & 7.95 & 7.50 & 8.83 & 7.95 & 7.50 & 8.83 & 7.95 & 7.50 & 8.83 & 7.95 & 7.50 & 8.82 & 7.95 & 7.50 \\
\hline Tryptophan, g/kg & 2.48 & 2.23 & 2.08 & 2.48 & 2.23 & 2.08 & 2.48 & 2.23 & 2.08 & 2.48 & 2.23 & 2.08 & 2.48 & 2.23 & 2.08 \\
\hline Available phosphorus, $\mathrm{g} / \mathrm{kg}$ & 4.50 & 4.20 & 3.80 & 4.50 & 4.20 & 3.80 & 4.50 & 4.20 & 3.80 & 4.50 & 4.20 & 3.80 & 4.50 & 4.20 & 3.80 \\
\hline Calcium, g/kg & 9.00 & 8.40 & 7.60 & 9.00 & 8.40 & 7.60 & 9.00 & 8.40 & 7.60 & 9.00 & 8.40 & 7.60 & 9.00 & 8.40 & 7.60 \\
\hline Chloride, g/kg & 2.00 & 2.00 & 2.00 & 2.00 & 2.00 & 2.00 & 2.00 & 2.00 & 2.00 & 2.00 & 2.00 & 2.00 & 2.00 & 2.00 & 2.00 \\
\hline Sodium, g/kg & 1.70 & 1.70 & 1.70 & 1.70 & 1.70 & 1.70 & 1.70 & 1.70 & 1.70 & 1.70 & 1.70 & 1.70 & 1.70 & 1.70 & 1.70 \\
\hline Total phosphorus, g/kg & 5.93 & 5.49 & 4.95 & 5.90 & 5.47 & 4.94 & 5.89 & 5.47 & 4.94 & 5.88 & 5.46 & 4.93 & 5.87 & 5.45 & 4.92 \\
\hline
\end{tabular}

S: starter diet, G: grower diet, F: finishing diet 


\section{Results and Discussion}

Initial weight, average daily gain and average feed intake were not $(P>0.05)$ influenced by supplementation with various levels of $\mathrm{nCaHPO}_{4}$ (Table 3). However, final weight gain $(\mathrm{kg})$ and feed conversion ratio of birds were $(P<0.05)$ affected by the treatments. Birds fed $40 \% \mathrm{nCaHPO}$ had the highest final weight, which was greater than those not supplemented with $\mathrm{nCaHPO}_{4}$. Birds fed the other diets had final weights that were intermediate between these extremes. Birds fed $40 \% \mathrm{nCaHPO} 4$ were most efficient, whereas those fed $80 \% \mathrm{nCaHPO} 4$ had the greatest feed conversion ratio.

Table 3 Effect of various dietary levels of levels of nano-dicalcium phosphate on growth performance of broiler chickens

\begin{tabular}{lcccccc}
\hline \multirow{2}{*}{ Performance trait } & \multicolumn{9}{c}{ Nano-dicalcium phosphate level } & \multirow{2}{*}{ SE } \\
\cline { 2 - 5 } & $0 \%$ & $40 \%$ & $60 \%$ & $80 \%$ & $100 \%$ & \\
\hline Initial weight & 241.20 & 242.45 & 243.93 & 231.20 & 244.78 & 5.10 \\
Final weight & $1592.25^{\mathrm{b}}$ & $1715.10^{\mathrm{a}}$ & $1628.00^{\mathrm{ab}}$ & $1626.85^{\mathrm{ab}}$ & $1638.78^{\mathrm{ab}}$ & 5.35 \\
Average daily gain & 48.26 & 52.58 & 49.43 & 49.85 & 49.78 & 0.72 \\
Daily feed intake & 68.75 & 64.48 & 70.03 & 73.10 & 70.08 & 1.49 \\
Feed conversion ratio & $1.43^{\mathrm{ab}}$ & $1.23^{\mathrm{b}}$ & $1.40^{\mathrm{ab}}$ & $1.48^{\mathrm{a}}$ & $1.40^{\mathrm{ab}}$ & 0.03 \\
\hline
\end{tabular}

${ }^{a, b}$ Within a row, values with a common superscript were not different with probability $P=0.05$

The levels of nCaHPO4 provided in the diets had no detectable effects $(P>0.05)$ on the haematological profile of the broiler chickens (Table 4).

Table 4 Influence of various dietary levels of nano-dicalcium phosphate on haematology of broiler chickens

\begin{tabular}{lrrrrrrrr}
\hline \multirow{2}{*}{ Value } & \multicolumn{9}{c}{ Nano-dicalcium phosphate level } & & \multirow{2}{*}{ SE } & P-value & Reference ranges \\
\cline { 2 - 5 } & \multicolumn{1}{c}{$0 \%$} & $40 \%$ & $60 \%$ & $80 \%$ & $100 \%$ & & & \\
\hline HGB, g/dL & 6.74 & 6.55 & 6.10 & 8.85 & 6.33 & 0.49 & 0.084 & $0.09-8.05^{1}$ \\
RBC, $\times 10^{6} / \mu \mathrm{L}$ & 2.27 & 1.83 & 2.50 & 2.00 & 2.43 & 0.11 & 0.411 & $0.04-2.69^{1}$ \\
MONO, \% & 7.20 & 6.33 & 9.00 & 7.50 & 13.33 & 1.03 & 0.325 & $0.90-10.51^{1}$ \\
EOS, \% & 2.28 & 2.40 & 3.63 & 2.60 & 3.00 & 0.28 & 0.575 & $1.50-3.40^{2}$ \\
LYM, \% & 79.50 & 83.50 & 79.05 & 73.98 & 61.73 & 3.23 & 0.116 & $3.49-52.50^{1}$ \\
\hline
\end{tabular}

HGB: haemoglobin, RBC: red blood cell count, MONO: monocytes, EOS: eosinophils, LYM: lymphocytes Sources: ${ }^{1}$ Kuttappan et al. (2013), ${ }^{2}$ Abdi-Hachesoo et al. (2011)

With the exception of alkaline phosphatase, the serum biochemical constituents were influenced $(P$ $<0.05$ ) by various levels of $\mathrm{nCaHPO}_{4}$ (Table 5). Total protein concentration in the serum was increased for birds fed the $60 \% \mathrm{nCaHPO}_{4}$ diet compared with the other treatments. Serum albumin was lower in birds fed the $0 \%, 80 \%$, and $100 \%$ levels of nCaHPO4 and higher in those provided the $40 \%$ and $60 \%$ diets. The birds that were fed the $0 \%, 40 \%, 60 \%$, and $80 \% \mathrm{nCaHPO}_{4}$ diets had higher globulin levels than those fed the $100 \%$ diet. Birds fed the $60 \% \mathrm{nCaHPO}_{4}$ diet had higher levels of alanine transaminase in the serum, followed by the $0 \%$ and $100 \%$ groups and those fed the $40 \%$ and $80 \%$ diets had the lowest values. Cholesterol levels were higher when the $0 \%$ and $40 \%$ diets were fed compared with those from bird fed diets containing higher levels of $\mathrm{nCaHPO}_{4}$. Similar high mean values of serum calcium and phosphorus concentrations were observed when $0 \%, 40 \%, 60 \%$, and $100 \%$ diets were fed compared with $80 \% \mathrm{nCaHPO}_{4}$. 
Table 5 Effect of various levels of nano-dicalcium phosphate on serum constituents of boiler chickens

\begin{tabular}{|c|c|c|c|c|c|c|c|c|}
\hline \multirow{2}{*}{ Constituents } & \multicolumn{5}{|c|}{ Nano-dicalcium phosphate level } & \multirow{2}{*}{ SE } & \multirow{2}{*}{$P$-value } & \multirow{2}{*}{ Reference ranges } \\
\hline & $0 \%$ & $40 \%$ & $60 \%$ & $80 \%$ & $100 \%$ & & & \\
\hline $\mathrm{TP}, \mathrm{g} / \mathrm{L}$ & $82.33^{b}$ & $81.67^{b}$ & $115.67^{a}$ & $86.00^{b}$ & $71.33^{b}$ & 5.34 & 0.047 & $23.8-52.2^{1}$ \\
\hline ALB, $g / L$ & $22.33^{\mathrm{b}}$ & $25.00^{\mathrm{ab}}$ & $33.00^{\mathrm{a}}$ & $20.67^{b}$ & $23.67^{b}$ & 1.54 & 0.035 & $11.7-52.2^{1}$ \\
\hline GLU, g/ L & $59.00^{\mathrm{ab}}$ & $56.00^{\mathrm{ab}}$ & $81.00^{\mathrm{a}}$ & $51.33^{\mathrm{ab}}$ & $48.00^{b}$ & 4.76 & 0.032 & $11-27.75^{2}$ \\
\hline$A L T, I U / L$ & $69.00^{\mathrm{bc}}$ & $58.67^{\mathrm{cd}}$ & $92.33^{\mathrm{a}}$ & $52.50^{d}$ & $75.33^{b}$ & 4.16 & 0.043 & 19 to $50^{3}$ \\
\hline ALKP, U/L & 1893.0 & 1597.7 & 1739.7 & 1947.0 & 1761.7 & 64.6 & 0.002 & $568-8,831^{1}$ \\
\hline $\mathrm{CHOL}, \mathrm{mmol} / \mathrm{L}$ & $5.08^{\mathrm{a}}$ & $4.95^{\mathrm{a}}$ & $3.80^{b}$ & $4.06^{\mathrm{b}}$ & $4.01^{\mathrm{b}}$ & 0.18 & 0.023 & $2.25-4.97^{1}$ \\
\hline $\mathrm{P}, \mathrm{mg} / \mathrm{mL}$ & $5.13^{\mathrm{ab}}$ & $4.64^{\mathrm{ab}}$ & $5.80^{\mathrm{a}}$ & $4.55^{\mathrm{b}}$ & $4.88^{\mathrm{ab}}$ & 0.18 & 0.031 & $3.59-11.40^{1}$ \\
\hline $\mathrm{Ca}, \mathrm{mg} / \mathrm{mL}$ & $3.20^{\mathrm{ab}}$ & $2.99^{\mathrm{ab}}$ & $4.00^{\mathrm{a}}$ & $2.54^{\mathrm{b}}$ & $2.78^{\mathrm{ab}}$ & 0.19 & 0.031 & $4.70-16.25^{1}$ \\
\hline
\end{tabular}

a,b,c,d Within a row, values with a common superscript were not different with probability $P=0.05$

TP: total protein, ALB: albumin, GLU: globulin, ALT: alanine transaminase, ALKP: alkaline phosphatase, $\mathrm{CHOL}$ :

cholesterol, P: phosphorus, Ca: calcium

Sources: ${ }^{1}$ Meluzzi et al. (1992), ${ }^{2}$ Abdi-Hachesoo et al. (2011), ${ }^{3}$ Lumeij (1997)

Table 6 indicates the length and width of the ileum, duodenum and jejunum of broilers fed various levels of nano-dicalcium phosphate. All parameters were $(P<0.05)$ influenced by nCaHPO 4 . Birds fed $40 \%$ generally had larger intestinal tracts than those fed $0 \%, 60 \%, 80 \%$, and $100 \%$. The length of the duodenum was increased when $100 \% \mathrm{nCaHPO}_{4}$ was fed to the birds, with the $80 \%$ diet producing a shorter duodenum. Substitution levels of $40 \%$ and $60 \% \mathrm{nCaHPO}_{4}$ increased the length of the jejunum compared with the $0 \%$, $80 \%$ and $100 \%$ diets. The ileum width was reduced when $0 \%$ and $80 \%$ diets were fed compared with $40 \%$, $60 \%$ and $100 \% \mathrm{nCaHPO}_{4}$. The width of the duodenum was unchanged by the dietary treatments.

Table 6 Effect of various levels of nano-dicalcium phosphate in broiler diets on intestinal morphology

\begin{tabular}{lrrrrrr}
\hline \multirow{2}{*}{ Measurement } & \multicolumn{5}{c}{ Nano-dicalcium phosphate level } & SE \\
\cline { 2 - 6 } & \multicolumn{1}{c}{$0 \%$} & $40 \%$ & $60 \%$ & $80 \%$ & $100 \%$ & $277.56^{\mathrm{b}}$ \\
\hline lleum length, $\mu \mathrm{m}$ & $253.50^{\mathrm{b}}$ & $428.12^{\mathrm{a}}$ & $325.70^{\mathrm{b}}$ & $295.26^{\mathrm{b}}$ & 18.94 \\
\hline Duodenum length, $\mu \mathrm{m}$ & $370.86^{\mathrm{bc}}$ & $498.76^{\mathrm{ab}}$ & $366.83^{\mathrm{bc}}$ & $326.39^{\mathrm{c}}$ & $507.39^{\mathrm{a}}$ & 25.13 \\
\hline Jejunum length, $\mu \mathrm{m}$ & $450.99^{\mathrm{b}}$ & $637.88^{\mathrm{a}}$ & $598.43^{\mathrm{a}}$ & $390.70^{\mathrm{b}}$ & $394.73^{\mathrm{b}}$ & 32.61 \\
\hline lleum width, $\mu \mathrm{m}$ & $42.50^{\mathrm{b}}$ & $74.46^{\mathrm{a}}$ & $55.81^{\mathrm{ab}}$ & $42.84^{\mathrm{b}}$ & $65.16^{\mathrm{ab}}$ & 4.52 \\
\hline Duodenum width, $\mu \mathrm{m}$ & 54.46 & 79.95 & 53.63 & 68.09 & 72.34 & 4.60 \\
\hline Jejunum width, $\mu \mathrm{m}$ & $68.20^{\mathrm{b}}$ & $102.05^{\mathrm{a}}$ & $68.02^{\mathrm{b}}$ & $60.85^{\mathrm{b}}$ & $71.36^{\mathrm{ab}}$ & 5.39 \\
\hline
\end{tabular}

${ }^{a, b, c}$ Within a row, values with a common superscript were not different with probability $P=0.05$

The current study is in line with that of Hassan et al. (2016), in which they observed that various levels of $\mathrm{nCaHPO}$ enhanced bodyweight gain and feed conversion of broiler chicks compared with conventional dicalcium phosphate. In a related study, Ahmadi \& Famadi (2018) observed similar results for supplementation with nano-selenium.

The increasing levels of $\mathrm{nCaHPO}_{4}$ produced no detectable effects on the haematology of the chickens, and all values fell within the normal ranges for healthy chickens (Kuttappan et al., 2013; AbdiHachesoo et al., 2011) Thus, these dietary modifications were deemed to have no negative effects that might cause anaemia, infection and negative implications in the birds (Obikaonu et al., 2011). The results of the present study agree with those observed by Vijayakumar and Balakrishnan (2015), who reported that calcium phosphate nanoparticles did not exert a significant influence on haemoglobin, packed cell volume, total erythrocyte count, total leucocyte count, and differential count of white blood cells compared with the 
control group fed with conventional dicalcium phosphate. Thus supplementation of calcium phosphate nanoparticles instead of conventional dicalcium phosphate had no effect on the health of the birds, which reinforced the safe use of nanomineral supplements.

Non-significantly different alkaline phosphatase values were within the normal range of 568-8831 U/L (Meluzzi et al., 1992). The significantly higher total protein levels in the current study were above the normal range (23.8 - $52.2 \mathrm{~g} / \mathrm{L})$ reported by Meluzzi et al. (1992). However, they were similar to those observed by Rezende et al. (2017), who reported higher serum protein concentration in female birds. Fallah et al. (2018) reported no significant influence of calcium and protein concentrations in broilers at 21 days old. They added that increasing calcium concentration from $4.0 \mathrm{~g} / \mathrm{kg}$ to $5.5 \mathrm{~g} / \mathrm{kg}$ raised serum phosphate to a maximum concentration at a later stage. Serum proteins are produced in the liver and their functions include blood maintenance through the colloidal osmotic effect, metabolism regulation, and body defence against foreign agents (Tóthová et al., 2019). Blood plasma proteins play vital roles in the transportation of minerals and hormones (Piotrowska et al., 2011; Rezende et al., 2017). Higher levels of total proteins in the current study indicated that $\mathrm{nCaHPO}_{4}$ was available in the blood system. Therefore, it would enhance the production of fibrinogen, which is one of the coagulation factors. The results of the current study for increased levels of total protein may be explained by Tóthová et al. (2019), who reported that transitions in nutrition, and variations in diet composition and feed consumption during growth alter the metabolic rate and physical condition of growing chickens, which may be associated with changes in total protein in the serum.

Albumin concentrations were similar to those reported by Meluzzi et al. (1992) and Rezende et al. (2017). On the other hand, globulin concentration $(48.00-81.00 \mathrm{~g} / \mathrm{L})$ was above normal range $(11-27.75$ $\mathrm{g} / \mathrm{L}$ ) recorded by Abdi-Hachesoo et al. (2011). Serum albumin can increase gradually with age, reaching the highest level on days 32 and 46 of fattening (Tóthová et al., 2019). This could be attributed to maintaining the metabolic balance during rapid growth. In a similar study, Piotrowska et al. (2011) reported the highest value of $17.1 \mathrm{~g} / \mathrm{L}$ for albumin in broiler serum. Al-Beitawi et al. (2016) reported that total protein, albumin and globulin $(\mathrm{mg} / \mathrm{dl})$ increased significantly at 28 days old when $2 \%$ nano-clay minerals were added in broiler feeds. They added that at 36 days old, total protein and globulin concentration were increased when $1 \%$ and $2 \%$ nano-clay minerals were added compared with other dietary treatments. Cholesterol levels (3.80 - 5.08 $\mathrm{mmol} / \mathrm{L}$ ) in this current study were within the range of $2.25-4.97 \mathrm{mmol} / \mathrm{l}$ reported by Meluzzi et al. (1992). This indicated that an increase in $\mathrm{nCaHPO}_{4}$ in the feed could help maintain normal levels of cholesterol concentration in the blood. Meanwhile, a similar study (Rezende et al., 2017) showed that the cholesterol levels were higher in broiler females than males. Age, diet, and reproduction activity could also influence cholesterol levels. Findings by Al-Beitawi et al. (2016) showed that cholesterol levels, high-density lipoproteins, and triglycerides in the serum of chickens were influenced significantly by the addition of $2 \%$ nano-clay minerals once a week or once in two weeks in broiler diets.

In the present study, the patterns of serum calcium and phosphorus were inexplicable with the $60 \%$ treatment producing significantly higher levels of both minerals than the $80 \%$ treatment. However, neither of these levels were significantly different from those observed at the $0 \%, 40 \%$ and $100 \%$ levels and all values were within the normal ranges. Serum calcium concentrations in this study were lower compared with 4.70 $16.25 \mathrm{mg} / \mathrm{Ml}$ reported by Meluzzi et al. (1992). However, the phosphorus concentrations in this study were comparable with the $4.55-580 \mathrm{mg} / \mathrm{mL}$ range reported by Meluzzi et al. (1992) for clinically healthy birds. The observed difference in serum calcium levels could be attributed to variations because of sex, reproductive organs, high temperatures, age, and forms of calcium phosphate employed in this present study (Dutta et al., 2013). Ansar et al. (2004) also reported a significant difference on serum phosphorus level in chicks fed a control diet. The findings of the current study are not in agreement with those observed by Vijayakumar and Balakrishnan (2015), who reported no significant influence among treatments when calcium phosphate nanoparticles were supplemented in broiler diets. Silva et al. (2007) were of the opinion that variations in mineral components of blood usually differ with age owing to physiological changes that happen during each developmental phase.

The histology results from this study indicated a significant increase in the length and width of the ileum, jejunum, and duodenum of birds fed various levels of $\mathrm{nCaHPO}_{4}$. The increase in villi length and width in the current study could be attributed to improved absorption and utilization because of properties of nanoparticle size. The greater surface area and absorption capacity are associated with longer villi, which results in mature enterocytes on the villus tips, whereas poor nutrient absorption and digestion is an indicator of shorter villi which results in decrease absorptive area and less mature enterocytes (Paiva et al., 2014). Abdulla et al. (2016) reported that birds fed $6 \%$ soybean and palm oil in combination with levels of calcium, $1 \%$, and $1.25 \%$ had greater villi height for duodenum and jejunum compared with those fed linseed oils with $1.5 \%$ calcium. They also reported a [thannon-significant difference for the ileum height for all treatments. Pohl et al. (2012), in agreement with the current study, observed a significant increase on the duodenal villus height when $10 \%$ calcium formate was included in diets of broilers when compared with broilers exclusively 
fed calcium carbonate as a calcium source. However, these authors observed a non-significant influence on the villi width of duodenum because of the dietary treatments. Sawors et al. (2013) and Al-Beitawi (2016) observed that nano-clay minerals could exert a positive effect on tissue development.

\section{Conclusion}

Replacement of limestone and monocalcium phosphate with $\mathrm{nCaHPO}_{4}$ might improve the health status of broilers, as indicated by serum constituents and their increased level of intestinal development. Dicalcium phosphate was more effective and efficient when used in nano form $(40 \%-60 \%)$ than conventional particles, which could be the result of high availability, minute particle size and bioactivity of the nanoparticles. Nano-dicalcium phosphate substituted in diets at levels of $40 \%$ and $50 \%$ could improve broiler immunity and intestinal morphology.

\section{Acknowledgements}

The authors wish to thank North-West University management for financial support during the project

\section{Authors' Contributions}

AOY and LEM were in charge of project design and implementation, and writing the manuscript. MDM was in charge of field experimentation and draft write up, and MDM and TOA formatted and proofread the manuscript and rechecked the data analysis methods. AOY and LEM were responsible for data analysis and interpretation.

\section{Conflict of Interest Declaration}

The authors declare that there was no conflict of interest in this research

\section{Reference}

Abdi-Hachesoo, B., Talebi, A. \& Asri-Rezaei, S., 2011. Comparative study on blood profiles of indigenous and Ross-308 broilers. Bree. Glob. Vet. 7(3), 238-241.

Abdulla, N.R., Lohl, T.C., Akitl, H., Sazili, A.Q., Foo, H.L., Mohamad, R., Abdul Rahim, R., Ebrahimi, M. \& Sabowl, A.B., 2015. Fatty acid profile, cholesterol and oxidative status in broiler chicken breast muscle fed different dietary oil sources and calcium levels. S. Afr. J. Anim. Sci. 45(2), 153-163. http://dx.doi.org/10.4314/sajas.v45i2.6

Ahmadi, M. \& Famadi, F. 2011. The effect of different levels of nanosilver on performance and retention of silver in edible tissues of broilers. World Appl. Sci. J. 12(1), 01-04.

Al-Beitawi, N.A., Shaker, M.M., Khaled, N. \& Bláha, J., 2016. Effect of nanoclay minerals on growth performance, internal organs and blood biochemistry of broiler chickens compared to vaccines and antibiotics. J. Appl. Anim. Res. 45(1), 543-549. DOI: https://doi.org/10.1080/09712119.2016.1221827

Anwar, S., 2013. Effect of dietary supplementation of Catharanthus roseus on gross and micro-structure of selected internal organs of broilers. M. Phil. thesis, University of Veterinary and Animal Sciences, Lahore, Pakistan,.

Ansar, M., Khan, S.A., Chaudhary, Z.I., Mian, N.A., Tipu, MY. \& Rai, M.F., 2004. Effects of high dietary calcium and low phosphorus on urinary system of broiler chicks. Pak. Vet. J. 24(3), 113-116.

Applegate, J.T. \& Angel, R., 2014. Nutrient requirements of poultry publication: History and need for an update. J. Appl. Poult. Res. 23, 567-57. https://doi.org/10.3382/japr.2014-00980

Chen, H. \& Yada, R., 2011. Nanotechnoogies in agriculture: New tools for sustainable development. Trends. Food. Sci. Technol. 22(11), 585-594. https://doi.org/10.1016/j.tifs.2011.09.004

Daghir, N.J., 2009. Nutritional strategies to reduce heat stress in broilers and broiler breeders. Lohmann Information 44(1), 6-15.

Dutta, R. K., Islam, M.S. \& Ashraful Kabir, M.D., 2013. Haematological and biochemical profiles of Gallus indigenous, exotic and hybrid chicken breeds (Gallus domesticus I.) from Rajshahi, Bangladesh. Bangladesh J. Zool. 41(2), 135-144. https://doi.org/10.3329/bjz.v41i2.23314

Fallah, H., Karimi, C., Sadeghi, G.H. \& Behroozi-Khazaei, N., 2019. The effects of calcium source and concentration on performance, bone mineralisation and serum traits in male broiler chickens from 1 to 21 days of age. Anim. Prod. Sci. 59(6), 1090-1097. https://doi.org/10.1071/AN18166

Hassan, H.M.A., Samy, A., El-Sherbiny, A.E., Mohamed, M.A. \& Abd-Elsamee, M.O., 2016. Application of nanodicalcium phosphate in broiler nutrition: performance and excreted calcium and phosphorus. AJAVA 11, 477-483, DOI: 10.3923/ajava.2016.477.483

Hillyer, J.F. \& Albrecht, R.M., 2001. Gastrointestinal persorption and tissue distribution of differently sized colloidal gold nanoparticles. J. Pharm. Sci. 90(12), 1927-1936. https://doi.org/10.1002/jps.1143

Huang, S., Wang, L., Liu, L., Hou, Y. \& Li, L., 2015. Nanotechnology in agriculture, livestock, and aquaculture in China. A review. Agro. Sustain. Dev. 35(2), 369-400. DOI: 10.1007/s13593-014-0274-X

Kuttappan, V.A., Huff, G.R., Huff, W.E., Hargis, B.M., Apple, J.K., Coon, C. \& Owens C.M., 2013. Comparison of hematologic and serologic profiles of broiler birds with normal and severe degrees of white striping in breast fillets. Poult. Sci. 92(2), 339-345. DOI: https://doi.org/10.3382/ps.2012-02647

Lumeij, J.T., 1997. Avian clinical biochemistry. In: J.J. Kaneko, J.W. Harvey \& M.L. Bruss (eds). Clinical biochemistry of domestic animals. Academic Press, San Diego, CA. 857-883.

McDonald, P., Edwards, R.A., Greenhalgh, J.F.D., Morgan, C.A., Sinclair, L.A. \& Wilkinson, R.G., 2010. Animal nutrition. 7th edition. Prentice Hall. Hoboken, New Jersey, USA. 
Meluzzi, A., Primiceri, G., Giordani, R. \& Fabris, G., 1992. Determination of blood constituents reference values in broilers. Poult. Sci. 71(2), 337-345. https://doi.org/10.3382/ps.0710337

Nie, W., Wang, B., Gao, J., Guo, Y. \& Wang, Z., 2018. Effects of dietary phosphorous supplementation on laying performance, egg quality, bone health and immune responses of laying hens challenged with Escherichia coli lipopolysaccharide J. Anim. Sci. Biotechnol. 9(1), 53. https://doi.org/10.1186/s40104-018-0271-z

Obikaonu, H.O., Okoli, IC, Opara, M.N., Okoro, V.M.O., Ogbuew, I.P., Etuk, E.B. \& Udedibie, A.B.I., 2011. Heamatological and serum biochemical indices of starter broilers fed neem (Azadirachta indica) leaf meal. Online J. Anim. Feed. Res. 1(4), 150-154.

Paiva, D., Walk, C. \& McElroy, A., 2014. Dietary calcium, phosphorus, and phytase effects on bird performance, intestinal morphology, mineral digestibility, and bone ash during a natural necrotic enteritis episode. Poult. Sci. 93(11), 2752-2762. https://doi.org/10.3382/ps.2014-04148

Piotrowska, A., Burlikowska, K. \& Szymeczko, R., 2011. Changes in blood chemistry in broiler chickens during the fattening period. Folia Biol. 59(3-4), 183-187. DOI: 10.3409/fb59_3-4.183-187

Pohl, S.A., Caldwell, D. J., Lee, J. T., Coppedge, J.R., Dunn-Horrocks, S.L., Stringfellow, K. D., Jessen, K. \& Farnell, M.B., 2012. Effects of dietary calcium formate inclusion on broiler performance, skeletal development, and gut maturation. J. Appl. Poult. Res. 21(2), 311-317. https://doi.org/10.3382/japr.2011-00400

Rezende, M.S, Mundim, A., Fonseca, B.B, Miranda, R.L, Oliveira Jr., W. \& Lellis, C.G., 2017. Profile of serum metabolites and proteins of broiler breeders in rearing age. Brazilian J. Poult. Sci. 9(4), 583-586. https://doi.org/10.1590/1806-9061-2016-0338

Sawors, F., Pineda, L., Hotowy, A., Jaworski, S., Prasek, M. \& Sawors, E., 2013. Nanonutrition of chicken embryos. The effects of silver nanoparticles and ATP on expression chosen genes involved in myogenesis. Arch. Anim. Nutr. 67(5), 347-355.

Silva, P.R.L, Freitas, Neto O.C, Laurentiz, A.C, Junqueira, O.M. \& Fagliari, J.J., 2007. Blood serum components and serum protein test of hybro-pg broilers of different ages. Braz J. Poultry Sci. 9(4), $229-232$. https://doi.org/10.1590/S1516-635X2007000400004

Talaat, M.E., 2017. Application of nanotechnologies in poultry production. Nutri. Food Sci. Int. J. 3(1), 555610. DOI: 10.19080/NFSIJ.2017.03.555610. DOI: 10.19080/NFSIJ.2017.03.555610

Tóthová, C., Sesztáková, E., Bielik, B. \& Nagy, O., 2019. Changes of total protein and protein fractions in broiler chickens during the fattening period. Vet World. 12(4), 598-604. DOI: 10.14202/vetworld.2019.598-604

Vijayakumar, M.P. \& Balakrishnan, V., 2015. Effect of calcium phosphate nanoparticles supplementation on growth performance of broiler chicken. Indian J. Sci. Technol. 7(8), 1149-1154. DOI: 10.17485/ijst/2014/v7i8.20 